Pamiętnik Literacki 2020, 2, s. 109-117

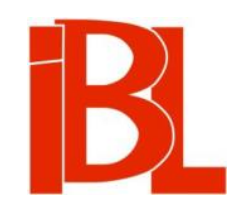

\title{
Dary dla Wenery. O fraszce "Do milości" (III 12) Jana Kochanowskiego i jej tradycjach orfickich
}

Jerzy Kroczak 


\section{DARY DLA WENERY O FRASZCE „DO MIŁOŚCI” (III 12) JANA KOCHANOWSKIEGO I JEJ TRADYCJACH ORFICKICH}

Wiersz 12 Ksiag trzecich z Fraszek Jana Kochanowskiego - Do Miłości - jest skierowanym do Wenery wezwaniem, zawierającym obietnicę złożenia jej ofiar na darniowym ołtarzu oraz prośbę o pomoc w sprawach miłosnych, zależnych od bogini, dwukrotnie nazwanej „szafarką trósk i radości” (w. 2 i 30) ${ }^{1}$. Już dawno Stanisław Windakiewicz poczynił w związku $\mathrm{z}$ tą fraszką słuszne spostrzeżenie: „Poeta składa ofiary Wenerze, z prośbą, aby mógł zaślubić ukochaną"2. Przytoczmy fragment ilustrujący jego tezę:

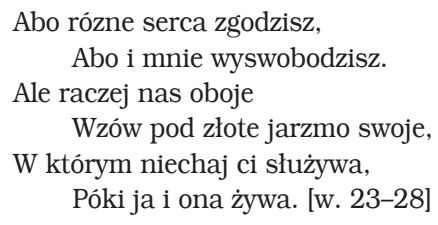

Jak ustalili badacze, utwór nawiązuje do ody Horacego (Carmina, I 19) oraz do

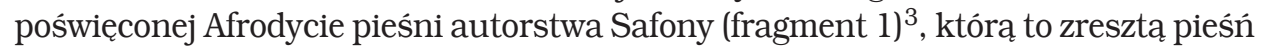
parafrazował w języku łacińskim sam Kochanowski i której parafrazę umieścił w zbiorze Lyricorum libellus z 1580 roku jako odę IX, Ad Venerem4. Rzeczywiście, incipit fraszki - „Matko skrzydlatych Miłości” - stanowi aluzję do słów „Mater saeva Cupidinum" z początku wskazanej ody Horacego; adresowany do bogini apel, by ta zstąpiła na złotym wozie zaprzężonym w ptaki (w. 3-5), znajduje odpowiednik u Safony (w. 8-10) odwołaniem do „świeżych darni” u Horacego (w. 13: „vivum [...] caespitem”); także kadzidło, o którym mówi Kochanowski (w. 13), występuje w odzie rzymskiego poety (w. 14: „verbenas [...] ponite turaque”). Kwestię zależności od wzorców antycznych

1 Cytaty według edycji: J. Kochanowski, Fraszki. Oprac. J. Pelc. Wyd. 3, przejrz. Wrocław 1998, s. 123-124. BN I 163.

2 S. Wind a ki e wi c z, Jan Kochanowski. Kraków 1930, s. 95.

3 Zob. J. Pelc: wstęp w: Ko ch a now ski, ed. cit., s. LXX; komentarz w: jw., s. 123.

4 O dwóch wersjach utworu Safony w łacińskim opracowaniu poety z Czarnolasu pisze J. Pelc (Kochanowski. Szczyt renesansu w literaturze polskiej. Warszawa 2001, s. 171). Zob. J. Ko c h an o w s k i, Ad Venerem. W: Carmina Latina / Poezja łacińska. Cz. 1: Fototypia, transkrypcja. Oprac. Z. Gło m bi ow ska. Gdańsk-Sopot 2008.

5 Przy czym u Kochanowskiego pojazd zaprzężony jest w łabędzie, u Safony zaś w drobne ptaki najpewniej wróble (strouthoí). W sprawie tych ostatnich zob. J. D a n i e le w i c z, komentarz w zb.: Liryka grecka. T. 2: Melika. Oprac. ... Warszawa-Poznań 1999, s. 130. 
zwięźle skomentował Janusz Pelc: „Pogłosy poezji greckiej przenikały do wierszy Kochanowskiego często pośrednio, por. np. Do Miłości (Fraszki, III 12), wiersz nawiąujący do Horacego, Carmina, I 19"6.

Na początku Ksiag trzecich Kochanowski umieścił kilka erotyków (noszących tytuły O Miłości lub Do Miłości), wyodrębnionych wyraźnie w cykl tematyczny, co Jacek Sokolski łączy z poprzedzającymi te utwory fraszkami poświęconymi lipie:

W świetle tego, co zostało [...] powiedziane o tradycyjnym pojmowaniu symbolicznego sensu lipy $\mathrm{w}$ folklorze narodów środkowoeuropejskich, takie nagromadzenie erotycznych wierszy w okolicy dwóch fraszek Na lipę nie powinno nas zaskakiwać ${ }^{7}$.

Fraszkę III 12 lokowano również wobec jeszcze szerszego zespołu wierszy - m.in. wobec Elegii i Pieśni Kochanowskiego - jako sekwencję informacji o przebiegu miłości poety ${ }^{8}$.

Nas w rzeczonym utworze interesuje zasadniczo jego część środkowa - opis darów składanych Wenerze - która była dotąd przedmiotem tylko marginalnej uwagi badaczy albo która skłaniała ich do przedstawiania mało przekonujących wyjaśnień.

Podmiot wiersza kieruje do bogini miłości następujące słowa:

A staw się na wiślnym brzegu,

Gdzie ku twej ćci ołtarz nowy

Stawię swą ręką darnowy.

Nie dam ci krwawej ofiary,

Bo co mają srogie dary

U boginiej dobrotliwej

Czynić i światu życzliwej?

Ale dam kadzidło wonne,

Które nam kraje postronne

Posyłają, dam i śliczne

Zioła w swych barwach rozliczne.

Masz fijołki, masz leliją,

Masz majeran i szałwiją.

Masz wdzięczny swój kwiat różany,

To biały, a to rumiany.

Tym cię błagam, o królowa

Bogatego Cypru [...] [w. 6-22]

Do darów roślinnych należą zatem zioła: majeranek i szałwia, a także kwiaty: fiołki, lilie i róże (białe oraz czerwone). W drugiej połowie XIX wieku Józef Gacki wykorzystał te wersy, by snuć domysły o gospodarstwie Kochanowskiego: „Córki mogły sobie urządzić kwietnik, jak go opisuje"9 . Jest jednak bardzo wątpliwe, byśmy mieli do czynienia $z$ instrukcją poety dla córek lub z opisem ich dokonań ogrodniczych; to nie walory estetyczne kwietników były pretekstem do wyliczenia takich, a nie innych roślin. Rozpatrując ową kwestię, Wiktor Weintraub wskazał na wers 16:

$6 \quad$ Pelc, Kochanowski, s. 344, przypis 15.

7 J. So kols ki, Lipa, Chiron i labirynt. Esej o „Fraszkach”. Wrocław 1998, s. 65-66.

8 Zob. T. Law en d a, Fraszki miłosne Jana Kochanowskiego. Paradygmat elegïny. Lublin 2018, rozdz. 3: Fraszki do Wenery i Amora.

9 J. Ga cki, O rodzinie Jana Kochanowskiego, o jej majętnościach i fundacjach. Kilkanaście pism urzędowych. Warszawa 1869, s. 117. 
„Zioła w swych barwach rozliczne”, i próbował rzecz objaśnić w perspektywie wyobraźni artystycznej Kochanowskiego, przekładającej się na tendencję do tworzenia „zestawień kolorystycznych”:

Jeśli - w co wolno powątpiewać - pozestawiał poeta te kwiaty dla kolorów, to otrzymalibyśmy tu trzy pary ostro odcinajacych się barw: biel i fiolet, niebieskofioletowy majeran (lebiodę) z krwistoczerwoną szałwią i białe oraz pąsowe róże $\mathrm{e}^{10}$.

Przyznać trzeba, że $z$ faktu zestawienia kolorów niewiele wynika, zresztą sam Weintraub opatrzył swoje domysły znamiennym zastrzeżeniem: „w co wolno powątpiewać".

Śladami motywów roślinnych podążyła też Olga Neveršilová, autorka jedynej (jaką udało nam się odnaleźć) publikacji, która w całości poświęcona jest fraszce III 12. Przez wzgląd na dary z kwiatów i ziół badaczka dostrzegła podobieństwo Wenery do Matki Boskiej, zwłaszcza tej czczonej pod przydomkiem Zielna, i przeanalizowała związki między Maryją a różami oraz typ kierowanych do Maryi modłów jako zaplecze kulturowe aktu opisanego przez renesansowego poetę ${ }^{11}$. O ile w szerszym planie antropologicznym rzeczywiście można mówić o pewnych paralelach między Matką Boską a Afrodyta, o tyle w przypadku tego wiersza trudno zgodzić się na propozycję badaczki.

Ciekawe na pierwszy rzut oka wydaje się poszukiwanie odwołań do medycznych lub magicznych własności wymienionych ziół i kwiatów, opierające się na założeniu, iż w tekstach erotyków pojawiają się nazwy roślin uznawanych za afrodyzjaki. Idąc takim tropem, Anna Dąbrowska wysunęła tezę, że Kochanowski musiał wiedzieć o „właściwościach roślin ekscytujących erotycznie”, a na jej potwierdzenie przytoczyła cytat $\mathrm{z}$ fraszki III $12^{12}$. Problem jednak w tym, że majeranek i szałwia (które autorka artykułu przedstawiła jako afrodyzjaki), ale też wyliczone w utworze Do Miłości kwiaty, w istocie nie wzmagają zapałów cielesnych - a przynajmniej milczą o tym zielniki i dzieła medyczne znane w XVI i XVII wieku (mam na myśli herbarze Stefana Falimirza, Marcina z Urzędowa i Szymona Syreniusza) ${ }^{13}$. Co więcej, w Regimen sanitatis medicorum Parisiensium [...], popularnym kompendium medycznym o średniowiecznej proweniencji, drukowanym w wieku XVI w Krakowie, mówi się wprost, że szałwia $\mathrm{z}$ dodatkiem kwiatu róży zmniejsza potencję:

\footnotetext{
Szałwija z rutą zmieszana

Czyni nam prześpieczne picia.

K temu przyłóż kwiat różany,

Bo to zbytnią miłość mniejszy ${ }^{14}$.
}

W. W e in tr a u b, Rzecz czarnoleska. Kraków 1977, s. 151.

O. N e ver šil ová, Venus, Mutter der Liebe. Zu Kochanowskis Fraszka III 12. W zb.: Jan Kochanowski - Ioannes Cochanovius (1530-1584). Materialien des Freiburger Symposiums 1984. Hrsg. R. Fi g g th. Freiburg 1987, s. 227-229.

A. D ą brows ka, „Złota dziewanna” $i$ „biodra brzozowe”. Nazwy roślin $w$ polskim słownictwie erotycznym (na materiale poetyckim). „Język a Kultura” t. 16 (2001), s. 47.

Chyba że weźmiemy pod uwage zapach, który pobudza zmysły. O związkach zapachów z erotyka

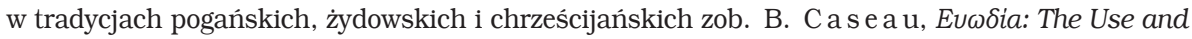
Meaning of Fragrances in the Ancient World and Their Christianization (100-900 AD). Rozprawa doktorska. Princeton University, 1994, s. 123-133.

F. Mymerus, Regimen sanitatis medicorum Parisiensium [...]. Kraków 1575, k. $\mathrm{B}_{2} \mathrm{r}$. Tu także 
Pięć roślin z interesujaccej nas fraszki ma według zielników liczne i różnorodne zastosowanie medyczne, ale nic osobliwego w sposób wyraźny ich nie łączy - ani pod względem własności magicznych czy astrologicznych, ani pod względem stopnia ciepłoty lub suchości ${ }^{15}$. Wspólny mianownik stanowi dla nich raczej to, że w naszej przestrzeni geograficznej - „na wiślnym brzegu” (w. 6) - sa nader zwyczajne ${ }^{16}$. Jak pisze Syreniusz: „Szałwija wszytkim prawie jest znajoma”, jej odmiana ogrodowa zaś „i dzieciom jest znajoma”, bo „zaledwie znaleźć tak mały i nędzny ogródek, w którym by nie była sadzona”; z kolei „Majeran znajomszy wszystkim jest”. Marcin z Urzędowa twierdzi: „Zna każdy fijołki, nie trzeba ich wypisować” 17.

Motywy fiołków, lilii i róż pojawiają się u Kochanowskiego częściej - także we Fraszkach (szczególnie w erotykach). W innym utworze zatytułowanym Do Miłości bogini Wenus jako łup otrzymuje zdjęty z głowy bohatera „wieniec fijołkowy” (III 33, w. 18) ${ }^{18}$; w wierszach Do dziewki mamy „lelija” (II 33, w. 9) oraz w wieńcu „przy różej leliją" (III 82, w. 4). Nic dziwnego, że zwłaszcza różę - tradycyjny kwiat Wenery i symbol miłości - poeta przywołuje w kontekstach erotycznych, np. w incipicie fraszki Na różą: „Nadobny sobie kwiat Wenus obrała” (II 8, w. 1). Ale „majeran” i „szałwija” to słowa, które w zachowanej twórczości Kochanowskiego występuja tylko raz (właśnie we fraszce III 12) ${ }^{19}$ i które zresztą są też dość rzadkie w całej literaturze dawnej. Warto zatem spytać - dlaczego akurat te zioła wybrał autor Fraszek?

„Majeran”, czyli majeranek, po łacinie maiorana (w nomenklaturze botanicznej: Origanum majorana L.), nazywany był przez Rzymian również zlatynizowanymi terminami pochodzenia greckiego: amaracum (gr. amárakon) oraz sampsuchum (gr. sámpsychon). Pliniusz Starszy, pierwszorzędny autorytet w dziedzinie historii naturalnej, przedstawił na jego temat znamienną uwagę: „sampsuchum sive amaracum in Cypro laudatissimum et odoratissimum", wskazujac Cypr jako miejsce, w którym rośnie najdoskonalszy i najbardziej wonny majeranek ${ }^{20}$. Ze względu na ową wyspę, ściśle związaną z kultem Wenery, oraz na mit o powstaniu majeranku,

wersja łacińska: „Salvia cum ruta faciunt tua pocula tuta, / Adde rosae florem, minuit potenter amorem".

15 Szerzej o różnych tradycjach klasyfikacji roślin oraz ich własności zob. G. Hardy, L. Totelin, Ancient Botany. London - New York 2016.

16 Zwracano już uwagę (zob. N. Korniłłowicz, Jasna strona renesansu. 〈O „Fraszkach” Jana Kochanowskiego〉. ,Ruch Literacki” 2003, z. 4, s. 362), że Kochanowski przenosi do swych utworów „bliskie stronom rodzinnym krajobrazy”, czego dowodem jest fraszka III 12: „na wiślanym brzegu stawić się miała na wezwanie poety Wenus".

17 Sz. Syreniu sz, Zielnik herbarzem z języka łacińskiego zowia [...]. Kraków 1613, s. 483 (II 30), 510 (II 41). - Mar cin z U rzę d ow a, Herbarz polski, to jest O przyrodzeniu ziót i drzew rozmaitych, $i$ innych rzeczy do lekarstw należacych księgi dwoje. Kraków 1595, s. 311 (I 366).

18 Fiołkowe wianki na głowach zakochanych mogą mieć związek ze zwyczajami ludowymi, ale odnotujmy też, że np. w Hymnach homeryckich Afrodycie przypisany jest epitet „uwieńczona fiołkami” (Hymn do Afrodyty 〈VI $\rangle$, w. 18).

19 Zob. Majeran. Hasło w: Stownik polszczyzny Jana Kochanowskiego. Red. M. Ku c ała. T. 2. Kraków 1998, s. 404. - Szałwija. Hasło w: jw., t. 4 (2008), s. 689.

20 C. Plinius Secundus, Naturalis historiae libri XXXVII. T. 3. Ed. C. May h off. Lipsiae 1892, s. 432 (XXI 163). U nas tę informację powtarza po polsku np. Marcin z Urzędowa (op. cit., s. 199 (I 228〉): „Plinius, lib. 21, cap. 22. Majeran w Cyprze jest nalepszy”. 
lokowany na Cyprze, roślina zaliczana jest do poświęconych bogini miłości ${ }^{21}$. Te informacje, szczególnie dotyczące aromatu, powtarzali dawniejsi i nowsi autorzy 22 . „Szałwija”, czyli szałwia, po łacinie salvia (w botanice: Salvia L.) lub elelisphacus (gr. elelisfakon), przez Pliniusza scharakteryzowana została jako roślina pachnacca (odorata): „Nostri, qui nunc sunt, herbarii 〈e〉lelisphacum Graece, salviam Latine vocant, [...] odoratam", i właśnie o tej jej cesze pisali też innii ${ }^{23}$. W ogóle w staropolskich tekstach często podkreśla się wonność wszystkich pięciu roślin z fraszki Do Miłości - Syreniusz wspomina, że szałwia jest „Liścia [...] barzo i wdzięcznie pachniącego”, w rozdziale $O$ majeranie notuje: „Wieńce rado $z$ niego wiją i na głowie noszą dla jego zapachu przyjemnego”, a o lilii pisze: „Kwiat zapachu pornego [tj. ostrego] i przyjemnego"; Marcin z Urzędowa przedstawia majeranek jako wartościowy „dla [...] [jego] wonności”; Falimirz radzi, by „W komorze mieć ziela wonne”, m.in. różę i „majoranę”; Mikołaj Rej zapewnia, iż „fijołek albo majeran [...] pięknie pachnie" ${ }^{24}$. Podobne przykłady można mnożyć. Do wonności darów dla Wenery powrócimy jeszcze za chwilę.

W kwestii kształtu literackiego fraszki III 12 interesująca uwagę wyraził Pelc:

Gdyby poeta utwór ów podzielił na osiem kwartyn izosylabicznych o rymach aa bb, bez przeszkód mógłby włączyć go do swoich ksiąg Pieśni, gdzie spotykamy utwory ułożone w takich właśnie strofach $^{25}$.

Kochanowski umieścił jednak swój erotyk jako wiersz niestroficzny we Fraszkach, co badacz opatrzył komentarzem: „Może dlatego właśnie, by i tu nie zabrakło w różnorodności wielkiej również i nawiązań do Horacego"26. Wydaje się, że przywołane konstatacje można uzupełnić o spostrzeżenie dotyczące tradycji literackiej, do jakiej w ten „pieśniowy” sposób mógł odesłać czytelnika Jan z Czarnolasu: jest nią starożytna tradycja hymniczna.

Nie chodzi nam wszakże o układane w heksametrach obszerne hymny homeryckie, w których będący adresatem hymnu bóg oraz jego czyny pozostają zasadniczym tematem narracji śpiewaka; pomijamy też hymny magiczne i należącą do liryki monodycznej pieśń do Afrodyty autorstwa Safony, wspomnianą na początku

Zob. J. Murr, Die Pflanzenwelt in der griechischen Mythologie. Innsbruck 1890, s. 195-196 (fragment rozdz. Heilige Pflanzen der Aphrodite).

O wykorzystywaniu wonności majeranku (także do produkcji pachnideł) oraz o jego zwiazkach z Afrodyta i z Cyprem zob. Sh. Butler, Making Scents of Poetry. W zb.: Smell and the Ancient Senses. Ed. M. B rad ley. London - New York 2015. Szerzej o roli zapachów zob. C. Cla s s en, D. How e s, A. Sy n n ott, Aroma: The Cultural History of Smell. London- New York 2003, rozdz. 1: The Aromas of Antiquity. Spośród dawniejszych autorów zob. np. Pedanius Dios corides, De materia medica. Transl. L. Y. B e c k. Hildesheim 2005, s. 198 (III 39, 1). Spośród nowszych zob. J. Ma s e n, Speculum imaginum veritatis occultae [...]. Coloniae Agrippinae 1681, s. 1033 (VII 80, 4).

23 C. Plinius Secundus, op. cit., s. 486 (XXII 147). Zob. też np. Pedanius Dioscorides, op. cit., s. 194 (III 33, 1). - Ma s e n, op. cit., s. 1071 (VII 80, 56).

24 Syreniusz, op. cit., s. 483 (II 30), 511 (II 41), 577 (II 65). - Marcin z Urzędowa, loc. cit. (I 228). - S. Fali mir z, O ziołach i o mocy jich. Kraków 1534, cz. 5, k. 62r. - M. Re j, Źwierciadło, albo Kstatt, $w$ którym każdy stan snadnie sie może swym sprawam jako we źwierciedle przypatrzyć. Kraków 1567-1568, k. 148v (III 5). 
$\operatorname{artykułu}^{27}$. Pragniemy za to wskazać na Hymny orfickie, reprezentujące grecką poezję kultową z II-IV wieku n.e. ${ }^{28}$ Są to utwory późne, w swym charakterze jednak dość archaiczne: utrzymane w nastroju podniosłym, krótkie (od 6 do 30 wersów) i pozbawione opowieści mitycznej, zawierające natomiast pochwałę bóstwa oraz w partii końcowej - wyraźnie wyodrębnioną prekację (modlitewną prośbę). O archaiczności świadczy też stosowana w nich często formuła „elthe [przybądź]”, za pomocą której przyzywano bóstwo, by we własnej osobie stawiło się na obrzędy, i dzięki której hymny zyskiwały wymiar kletyczny ${ }^{29}$. Kluczowa jest przy tym ofiara dla boga albo dla bogini, mająca skłaniać do przybycia - prawie przed każdym z 87 tekstów składających się na Hymny orfickie znajduje się informacja o substancji, która powinna zostać spalona w trakcie odśpiewywania utworu. We wstępie do polskiego tłumaczenia owego zbioru czytamy:

wiele razy powtarza się określenia thymiama aromata (wonne kadzidła) lub aromata poikila (różnorodne kadzidła), które nie oznaczają konkretnych wonności, lecz bliżej niesprecyzowaną pachnącą mieszankę roślin o właściwościach eterycznych ${ }^{30}$.

Co znamienne, ofiary miały charakter „bezkrwawy, lecz także niezwykle subtelny i miły dla zmysłów"31, odpowiadały upodobaniom danego bóstwa.

W kontekście przytoczonych uwag, zwłaszcza tych o roli kadzideł w Hymnach orfickich, wyjątkowo ciekawa wydaje się informacja z fraszki Do Miłości na temat dodatkowego daru złożonego Wenerze. Poeta wymienił go na pierwszym miejscu i poprzez podkreślenie obcego pochodzenia („dam kadzidło wonne, / Które nam kraje postronne / Posyłają", w. 13-15) przeciwstawił go pięciu wymienionym dalej, a omówionym przez nas roślinom.

We fraszce III 12 można odnaleźć istotne aluzje do wskazanej tradycji poetyckiej: pod względem formy jest to krótki utwór zdatny do śpiewania; ma charakter hymniczny, a jeszcze ściślej: kletyczny; dar dla Wenery autor nazwał bezkrwawym („Nie dam ci krwawej ofiary”, w. 9), ponadto wyjaśnił, dlaczego właśnie taka ofiara szczególnie nadaje się dla bogini („Bo co mają srogie dary / U boginiej dobrotliwej / Czynić i światu życzliwej?”, w. 10-12); wreszcie pojawił się tu motyw „kadzidła wonnego" (w. 13).

Wspomnieliśmy już, że Kochanowski określił dary jako „w swych barwach rozliczne" (w. 16) i że skłoniło to Weintrauba do podjęcia rozważań o kolorach roślin. Można i na ten wers spojrzeć przez pryzmat Hymnów orfickich, w których aromatyczne dary nazywane sa „thymíama poikíla”32. Grecki przymiotnik „poikílos” oznacza 'rozmaity', 'różnorodny', ale też 'barwny', 'kolorowy' - tak więc użyte przez Kochanowskiego sformułowanie ściśle odpowiada greckiemu „poikílos” i, jak się wydaje, stanowi świadome nawiązanie do sensów owego terminu.

Zob. J. D a ni ele wi c z, Hymn w systemie gatunków liryki greckiej. „Pamiętnik Literacki” 1986, z. 1 .

Korzystam z wydania: Orphei hymni. Ed. W. Q u a ndt. Berlin 1962. W wersji polskiej: Hymny orfickie. Przeł., oprac. E. Ży bert. Wstęp E. Żybert, J. Sokolski. Wrocław 2012.

Zob. E. Ży bert, J. S ok ols ki, wstęp w: Hymny orfickie, s. 5-10 (tu również dalsza literatura przedmiotu).

Ibidem, s. 31.

Ibidem, s. 32.

W tytułach hymnów 11 i 27 - zob. Orphei hymni, s. 12, 22. 
W zespole Hymnów orfickich znajduje się utwór Do Afrodyty (w nowoczesnych edycjach - nr 55), nie sprecyzowano w nim jednak, jakie wonności powinny być ofiarowane bogini ${ }^{33}$. Ten brak mógł stać się dla Kochanowskiego asumptem do przedstawienia własnego zestawu aromatycznych darów dla Wenery. Jest bowiem bardzo możliwe, że polski poeta znał Hymny orfickie; Pelc wyraził w owej kwestii jednoznaczną opinię: „Na pewno o hymnach orfickich dowiedział się wcześniej [niż w Paryżu - J. K.], najprawdopodobniej jeszcze w Polsce, a najpóźniej już podczas pobytów swych we Włoszech"34. Zresztą nie tylko osoby głęboko wtajemniczone, ale w ogóle czytelnicy zainteresowani tekstami greckimi mieli okazję, by zetknać się z tymi wierszami - wydał je po raz pierwszy Filippo Giunta w roku 1500, w wieku XVI ukazywały się kolejne ich edycje ${ }^{35}$, a w roku 1555 wyszedł drukiem nawet przekład łaciński (Orphei poetae vetustissimi opera) ${ }^{36}$. Dodajmy, iż prezentując takie zaplecze lekturowe poety z Czarnolasu, nie chcemy dowodzić, że szczególnie i w detalach zaciekawił go hymn Do Afrodyty ${ }^{37}$ i że o nim właśnie kazał pamiętać swoim czytelnikom - widzimy tu raczej ogólniejsze nawiązania do całego zbioru.

Dla czytelników XVI-wiecznych autorem omawianych tu tekstów hymnicznych był sam Orfeusz, a utwory - nie tylko zreszta hymny - stanowiły dowód istnienia tego arcypoety (choć sprawa nie była zupełnie jednoznaczna, renesansowi humaniści wskazywali bowiem, że teksty mu przypisywane powstawały w różnych czasach) ${ }^{38}$. Jak zauważył Sokolski, postać Orfeusza, odgrywająca pewną rolę w la-

33 Badacze tłumaczą to różnie. Być może po prostu wiedziano, jakie kadzidło pali się dla Afrodyty? A może należało zastosować specyfiki wskazane w hymnie poprzedzającym? A może brak wynika z przeoczenia kopisty? O hipotezach tych zob. Żybert, S o kols ki, op. cit., s. 33-34.

J. Pelc, Orfeusz pisarzy renesansowych. „Pamiętnik Literacki” 1979, z. 1, s. 80.

35 Zob. D. P. W alk e r, Orpheus the Theologian and Renaissance Platonists. „Journal of the Warburg and Courtauld Institutes” 1953, nr 1/2, s. 103, przypis 6. Wspomniana editio princeps ukazała się jako: Orphei Argonautica et hymni [...]. Florentiae 1500. Szerzej o dawnych wydaniach tekstów orfickich zob. L. Trzci on kowski, Fragment $w$ historii kultury. Zbiory fragmentów autorów antycznych jako semiofory. W zb.: Znakowe wartości kultury. Red. Z. Kloc h, Ł. G r ützm a c her, M. Kaźm i erczak. Warszawa 2014.

36 Zob. Pelc, Orfeusz pisarzy renesansowych, s. 71. O recepcji Hymnów orfickich i o zainteresowaniu nimi renesansowych humanistów zob. Ży bert, Sokols ki, op. cit., s. 40-46.

37 Na marginesie warto omówić jeszcze inne podobieństwo między analizowaną tu fraszką a tym hymnem. Najpierw jednak zauważmy, że we wspomnianej na początku niniejszego artykułu pieśni Safony rydwan bogini miłości prowadzą wróble i że ptaki te umieścił Kochanowski w swej łacińskiej odzie IX, Ad Venerem (zob. przypisy 4 i 5). We fraszce III 12 do wozu Wenery przypięte są łabędzie (w. 3-4), a właśnie w orfickim hymnie Afrodyta podróżuje „na zaprzężonym w łabędzie powozie” (Hymny orfickie, s. 91). Fakt ten, choć bardzo ciekawy, nie dowodzi wszakże, iż Kochanowski odwołał się do orfickiego utworu. Oto bowiem dopiero w nowoczesnych edycjach (Orphei hymni, s. 40. - Inni orfici. A cura di G. Ri c c i a rd el1i. Milano 2000, s. 146) czytamy o wozach i łabędziach (hymn 55, w. 20: „kykneíoisin óchois”), tymczasem we wszystkich znanych nam wydaniach XVI-wiecznych (Musaei opusculum de Herone et Leandro. Orphei Argonautica. Eiusdem hymni [...]. Venetiis 1517, k. 55r. - Poetae Graeci principes heroici carminis [...]. [Parisiis] 1566, cz. 2, s. 118) mamy w tym miejscu inną lekcję: „kyanéois óchthois [ciemnoniebieskie wzniesienia]”. Dodajmy, że na greckich przedstawieniach wazowych łabędzie występują z Afrodytą, ale dopiero u rzymskich poetów sa to ściślej związane z nią ptaki - zob. Kykons. Hasło w: W. G. Arnott, Birds in the Ancient World from A to Z. London - New York 2007, s. 183.

38 Zob. Walker, op. cit., s. 104. - Pelc, Orfeusz pisarzy renesansowych, s. 53. - Żybert, Sokols ki, op. cit., s. 46. 
biryntowej kompozycji Fraszek, pojawia się na początku Ksiag trzecich w wierszu Na lipe (II 6, w. 10), wprost po imieniu jest o nim mowa również w utworze noszącym także tytuł Do Miłości (III 10, w. 8), a w wierszu Do poetów (III 14, w. 4) przywołano go omownie jako „Nauczonego syna pięknej Kallijopy”39. Co ciekawe, w ostatnim przypadku Kochanowski aluzyjnie odesłał odbiorców właśnie do tradycji orfickiej - wizyta Argonautów u Chirona, podczas której centaur i Orfeusz odbyli agon poetycki, została obszernie opisana w greckim poemacie Argonautyki orfickie, też przecież przypisywanym Orfeuszowi ${ }^{40}$. Uważamy, że listę odwołań do mitycznego śpiewaka można uzupełnić o nieoczywiste i subtelne odesłanie do związanej z nim tradycji hymnicznej, która przejawia się w utworze Do Miłości (III 12), przy czym oczywiście należy założyć pewne wyrafinowanie ówczesnych odbiorców, pozwalające im odczytać tego rodzaju aluzje.

Jak wspomnieliśmy, Pelc zauważył w omawianej przez nas fraszce „pogłosy poezji greckiej” przenikające poprzez Horacego. Do twórczości łacińskiego poety Kochanowski niewątpliwie się odwołał - choć chyba trochę przewrotnie: $\mathrm{w}$ pieśni rzymskiego autora „sroga” jest Wenera (w. 1), u Jana z Czarnolasu „srogie” są natomiast niewłaściwie dobrane dary (w. 10). Naszym celem było uzupełnienie uwagi Pelca poprzez wskazanie tradycji literackiej czerpanej bezpośrednio ze źródła greckiego.

I jeszcze ostatni problem. Modlitwa kierowana do Wenery w utworze Kochanowskiego odnosi się do wpływu bogini na świat w ogóle: „Tak po świecie niechaj wszędzie / Twoja władza wieczna będzie" (w. 31-32) ${ }^{41}$, a w planie prywatnym jest dwojaka prośbą: albo o wyzwolenie $z$ niedoli miłosnych, albo - czego bohater pożąda bardziej - o ustanowienie relacji w „złotym jarzmie”, trwającym - jak mówi „Póki ja i ona żywa” (w. 28). Ta matrymonialna perspektywa każe zapytać o tożsamość osoby określonej zaimkiem „ona”.

Odwołamy się znów do koncepcji labiryntowego układu Fraszek. W zbiorze wyodrębnia się cykl wierszy o Hannie, bohaterce związanej z liczbą 6 i z jej symbolicznymi właściwościami dotyczącymi miłości i małżeństwa ${ }^{42}$; ostatni imiennie poświęcony jej utwór, noszący numer 66 (graficznie są to dwie szóstki) w Księgach wtórych, traktuje o wymianie pierścieni między Hanną a poetą, co kojarzyć należy ze zmówinami czy zaręczynami, względem których stosunek bohaterki jest dość niejednoznaczny. Kolejna po szóstce liczba ściśle łącząca się w tradycji kultury $\mathrm{z}$ małżeństwem to dwunastka (tzw. numerus nuptialis) ${ }^{43}$, a właśnie pod tym numerem Kochanowski umieścił w Księgach trzecich interesujący nas wiersz Do Miłości,

S o kols ki, op. cit., s. 65-67.

Argonautyki orfickie. Przeł., oprac. E. Ży b ert. Wstęp E. Ży b ert, J. S ok ols ki. Wrocław 2011, s. 59-61, w. 376-454.

Por. wezwanie skierowane do Afrodyty z początku hymnu 55 (w: Hymny orfickie, s. 91, w. 5-6): „pod jarzmo swe wzięłaś świat cały, / trzema częściami wszechświata władając”.

O symbolicznych znaczeniach tej liczby zob. S o kols ki, op. cit., s. 24-28.

O liczbach weselnych (zwłaszcza o dwunastce), o ich sensach oraz o źródłach symbolicznego o nich myślenia pisze szerzej J. S o kols ki w rozdz. 3 przygotowywanej książki „Gdy słońce Raka zagrzewa...” Wokót „Sobótki” Jana Kochanowskiego. 
którego bohater wyraźnie zmierza do zawarcia małżeństwa ${ }^{44}$. Pociagająca jest myśl, iż bohaterka ukryta pod imieniem Hanna, która we fraszce II 66 niejednoznacznie zareagowała na zrękowiny, w obdarzonym nupcjalnym numerem utworze III 12 wobec modlitwy o dozgonny związek przeistacza się w realną postać ze świata poety - w jego żonę Dorotę ${ }^{45}$.

Panna XI z Pieśni świętojańskiej o sobótce prezentuje, jak wiadomo, pochwałę „nieprzepłaconej Doroty”. Nie wiemy, czy wcześniej powstała owa pieśń, czy fraszka III 12. Warto odnotować, że w opisie urody kobieta w pieśni zestawiona została z kwiatami; wprawdzie porównanie jest konwencjonalne, ale w tym przypadku wymienione zostały właśnie te rośliny, które bezpośrednio łączą Dorotę z pachnącymi darami składanymi bogini miłości: „Twarz jako kwiatki mieszane / Lelijowe i różane" 46 .

Ujawniająca się we fraszce perspektywa matrymonialna skłania do poczynienia jeszcze jednej uwagi o majeranku jako darze należnym Wenerze - matce miłości spajającej małżeństwa. Oto w tradycji literackiej wskazać można rzadko wykorzystywane przez antycznych poetów słowo „amaracum” (przypomnijmy, oznaczające 'majeranek') w wezwaniu skierowanym do Hymenajosa, patrona obrzędów weselnych ${ }^{47}$; w utworze Katullusa ma on przybyć na uroczystość ślubną, ozdobiwszy skronie „wieńcem uwitym z pachnącego majeranku” („suave olentis amaraci”) ${ }^{48}$. A zatem we fraszce Do Miłości (III 12) nie tylko modlitwa, lecz także wonny dar dla Wenery da się powiązać z planowanym małżeństwem, a nawet z literackim obrazem kobiety, która naprawdę stała się żoną Kochanowskiego.

\author{
Abstract \\ JERZY KROCZAK University of Wrocław \\ ORCID: 0000-0003-2415-1631
}

GIFTS FOR VENUS ON JAN KOCHANOWSKI'S TRIFLE "DO MIŁOŚCI"

(“TO LOVE") (III 12) AND ITS ORPHIC TRADITIONS

The paper refers to bloodless gifts for Venus described in Jan Kochanowski's $16^{\text {th }}$ c. poem Do Miłości (To Love) (Trifles, III 12), namely fragrant incense and colourful plants of strong scent (violets, lilies, marjoram, sage, roses) that may obtain graciousness of the goddess of love. Hymnic character of the piece and the expressions that it contains allow to establish connections of the trifle with the tradition of Orphic hymns that were known to the Renaissance humanists. The poem is interpreted from the perspective of its place in the collection of Trifles and Kochanowski's marriage plans.

44

45

Przypomnijmy, że identyczny tytuł noszą wiersze 10 i 11 z Ksiag trzecich - z tematyką małżeńską wiąże się jednak ten umieszczony pod numerem 12.

O innych możliwych analogiach między tymi bohaterkami zob. J. Kroczak, W labiryncie. O układzie „Fraszek”. W zb.: Wiazanie sobótkowe. Studia o Janie Kochanowskim. Red. E. La s ocińska, W. Pawlak. Warszawa 2015, s. 114-115.

J. Kochanowski, Pieśni. Oprac. L. Szczerbicka-Ślęk. Wyd. 3, zmien. Wrocław 1970, s. 110, w. 11-12. BN I 100.

Pochodzenie Hymenajosa przedstawiano różnie, ale jako jego matka wymieniana jest też Afrodyta. Katullu s, Poezje wszystkie. Przeł. G. Franczak, A. Klęc zar. Wstęp A. Klę czar. Indeksy metryczne K. W o ś. Kraków 2013, s. 358-359 (LXI, w. 7). 